\title{
Using of GIS Technology for Conservation of the Ottoman Bathroom and Its Urban Surrounding in Qena-Egypt
}

\author{
Essam H. Mohamed \\ Archaeological Conservation Department, Faculty of Archaeology, South Valley University, Qena, Egypt \\ Email: essam.mohamed@arch.svu.edu.eg
}

How to cite this paper: Mohamed, E. H. (2020). Using of GIS Technology for Conservation of the Ottoman Bathroom and Its Urban Surrounding in Qena-Egypt. Archaeological Discovery, 8, 26-46. https://doi.org/10.4236/ad.2020.81002

Received: October 16, 2019

Accepted: November 4, 2019

Published: November 7, 2019

Copyright $\odot 2020$ by author(s) and Scientific Research Publishing Inc. This work is licensed under the Creative Commons Attribution International License (CC BY 4.0).

http://creativecommons.org/licenses/by/4.0/

(c) (i) Open Access

\begin{abstract}
The Bathroom area in Qena city is suffering from urban, social and economic problems, which affects negatively on one of the most important Islamic buildings (the Ottoman Bathroom). In the present study, Geographic Information Systems (GIS) technique has been chosen for evaluating the current state of the Ottoman Bathroom and its urban surrounding that is situated within Qena city. Three categories of the evaluating were carried out, the urban, economic, and social status of the environment urban of the Bathroom. Monitoring and analysis of spatial and descriptive data were carried on the surrounding of the Bathroom through design the spatial database; the results of the study indicated that the residential buildings have been suffering from severe damage. The samples were collected from different places of the Bathroom, investigated by Scanning Electron Microscopy (SEM) with EDX analytical methods, and X-Ray Diffraction (XRD). The previous results were indicated that there is a crystallized salt in bricks pores, micro-cracks, and loss in the internal structure of the building materials. The conservation plan included on many steps: 1) documentation of the building and its urban surrounding; 2) monitoring of deterioration symptoms of the building, urban deterioration symptoms of the surrounding; 3 ) the conservation plan and adaptive reuse of the Ottoman Bathroom.
\end{abstract}

\section{Keywords}

GIS Technology, The Current State, The Ottoman Bathroom in Qena, Conservation, Rehabilitation, Adaptive Reuse, Intervention Suggestions

\section{Introduction}

The conservation of the local architectural heritage is one of the most important factors to conserve the local identity. These buildings are considered mind of the 
nation and the link between the past and the present which reflects the communication and continuity in civilization which is the best evidence of the cultural heritage and civilization through the different ages. The ottoman bathroom in Qena city is considered one of the important Islamic service facilities, as a necessity for people's health in their daily lives. Moreover, it represents a symbol of Islamic civilization in Qena city. GIS applications have spread widely throughout the world as an important technique, which use to support decision making in the development and management of archaeological sites, that require an inventory of natural and human resources, in order to develop appropriate plans and achieve optimum utilization and compatibility between the multiple uses of land and their representation and drawing (Chang, 2008; Lock, 2001; National Center for Geographic Information and Analysis, 1989). Geographic Information Systems (GIS) are considered an important tool used to evaluate the current state of archaeological sites, this technique has a high ability on monitoring, documentation, analysis, and other capabilities, that used in the evaluation, it has the ability in the creation of an integrated electronic database for the archaeological site (Aldenderfer \& Carolyn, 2000; Elphinstone \& Wickham-Jones, 2012), that allows more than user to access data and modify it simultaneously, saving a lot of time, effort, cost in the medium and long term, the studies related to using GIS techniques in the documentation and rehabilitation of the archaeological sites are still few (Wheatley \& Gillings, 2013; Rajani, 2016). the interrelationship between GIS and the documentation of archaeological sites is represented of the influence of each part to the other, showing the features of this effect either as a source for providing the scientific material or as an applied method or another, to contribute to the development of assumptions or future predictions that may arise on the natural and human phenomena represented by archaeological sites (Mekni, 2013). It is known that the most of the developed countries technically have become dependent on the basis of their work on GIS, especially in the providers of public services, this technique has been used in several fields, such as road planning, construction, and maintenance, identification of services types, villages, and towns (El Adnani et al., 2019; Ramsay, 2011), which have archaeological sites requirement access to various necessary information to determine traffic directions, control and regulation of traffic lights and the establishment of security patrol centers and points (Godchild et al., 1992; Moustafa, 2000; Meaden \& Aguilar-Manjarrez, 2013; El Adnani et al., 2019). GIS techniques are used in design of geometric vision through aerial photographs and maps to identify neglected heritage buildings, and how to reuse them, integrate them and use them in tourism activity, in addition, to find economic sources for financing, conservation of ancient buildings, so as not to lose the area value, specifically in the Ottoman Bathroom zone and its surrounding, so, it should be developed, rehabilitate and preserve. The digital maps of cultural heritage sites are represented, by layers, which are used to manage and develop the archaeological and tourist sites, and these layers contain all the information and natural and human components (Güney, 2001; Openshaw, 1991). In geographic information systems, 
the following steps are taken: Data Collection \& Correction. Spatial data include all forms of data for archaeological sites, that are associated with specific coordinates, the site is defined in a specific way in the form of coordinates (X-Y) or three dimensions (X. Y. Z.), the spatial data are divided into three sets of phenomena when represented in maps: Point features, Line features, and areal features (Lake, 1993; Akhter, 2018; Pickles, 2008). According to (Benavente et al., 2004), the experimental study, which carried on the stone samples affected by crystallization of sodium sulphate and sodium chloride showed that halite resort to deposit on the surface of the stone with a similar distribution in all samples. The present research has been oriented by the following hypothesis: In order to determine the values of the monument and its conservation, it must address the conservation of archeological buildings from an integrated holistic perspective of all means and principles.

- The archeological building and its built environment are an organic unit that should be dealt with from this point of view when thinking about its restoration or maintenance.

- There is an inverse relevance between the continuation of the archaeological building and damage factors affecting it. Whenever the risks increased the archaeological building, becomes more damaged and destroyed.

- Dealing with the laws of monuments, buildings and urban planning must be from an integrated holistic perspective that takes into account the unity and entity of the architectural heritage of the region.

- Strategies, policies, and objectives that achieve conservation of the buildings as a historical and archaeological value should be preceded by the study and identification of problems and risks that threaten these buildings and the urban environment.

- Adaptive reuse is the best way to the conservation of historic buildings, particularly a case of the Ottoman Bathroom.

The study deals with the conservation and reuse of the Ottoman Bathroom situated in Qena by using GIS technique to monitoring the current state of the building and its surrounding, which helps in visualize of the conservation and rehabilitation plan.

\section{The Ottoman Bathroom}

The Ottoman Bathroom is situated within scope of the second section of Qena city (Figure 1); this zone represents the old residential block of Qena city that existed at the beginning of 19th century AD.

\subsection{The Historical, Architectural and Functional Values}

The Ottoman Bathroom in Qena dating back to the late 18th century and the beginning of 19th century $\mathrm{AD}$. It was registered as archeological building according to the decree of Council of Ministers no. (332) of 2002 A.D. From the construction date of the building shows that it has a historical value represents in its age, which is more than 200 years, in addition to it is represented one of 
three Bathrooms remains in Upper Egypt (Osman, 2001). Function of the building is considered as a test that determines validity of the building design, where the building value is increased whenever; the building was suitable for its purposes. If we look at the architectural value of the Bathroom, we observe that its horizontal design is oriented to the interior, taking into consideration the privacy of the building, it has a diversity of the height of the architectural elements based on the function of each it, in addition to different of domes and vaulted roofing. The Ottoman Bathroom's layout principles are summarized in the following points: it has an entrance similar to the entrances of public buildings in the Mamluk period; it contained a strip room, and a durqac covered by a wooden skylight, iwans are covered by a wooden roof. The first house was to prepare the bather to receive heat, before and after use. In addition to the heat, it is contained the washbasin, spaces, a furnace, and facilities.

\subsection{Architectural Description of the Ottoman Bathroom}

The area of the Bathroom's architectural units is $29 \mathrm{~m}$ from north to south, 23.30 $\mathrm{m}$ from east to west. The building's borders are Street of the Bathroom in the north, the Qaysariya Street in the west, Grand Mosque Street in the south and Grand Mosque in the west (Figure 2 \& Figure 3).

\subsubsection{Facades}

The façades of the build are characterized by simplicity; the main facade is located in the northern side of the Bathroom where there is the main entrance in the eastern side, this face has two windows. The western façade has three windows similar to those on the northern façade. The southern façade has another entrance is located in the western side, its width less than the main entrance; this façade extends to a space where the furnace was located (Figures 4-7).

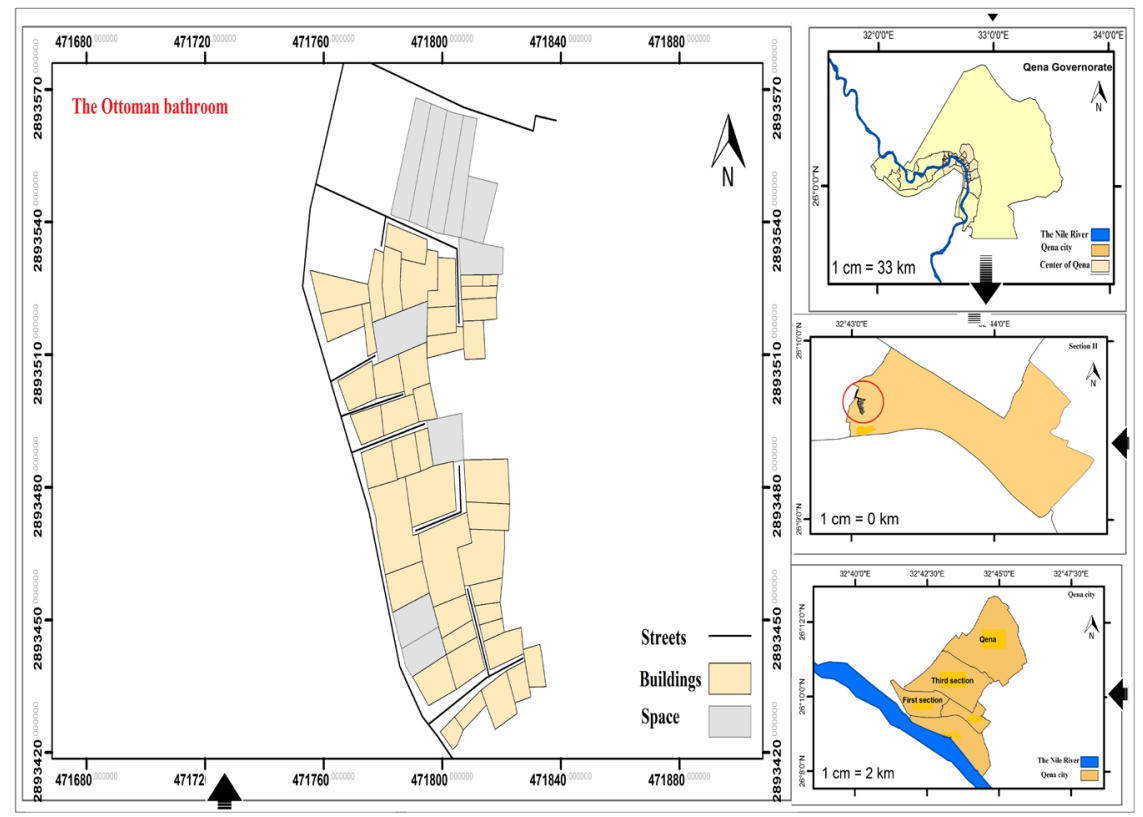

Figure 1. Site of the Ottoman Bathroom in Qena city. 


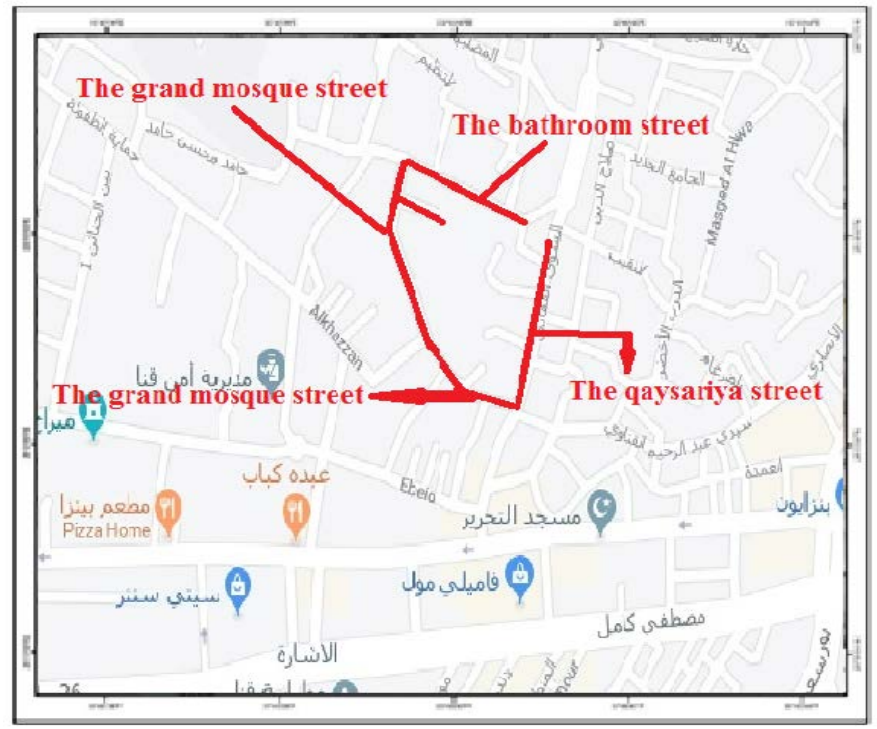

Figure 2. Geographic boundaries of the Ottoman Bathroom.

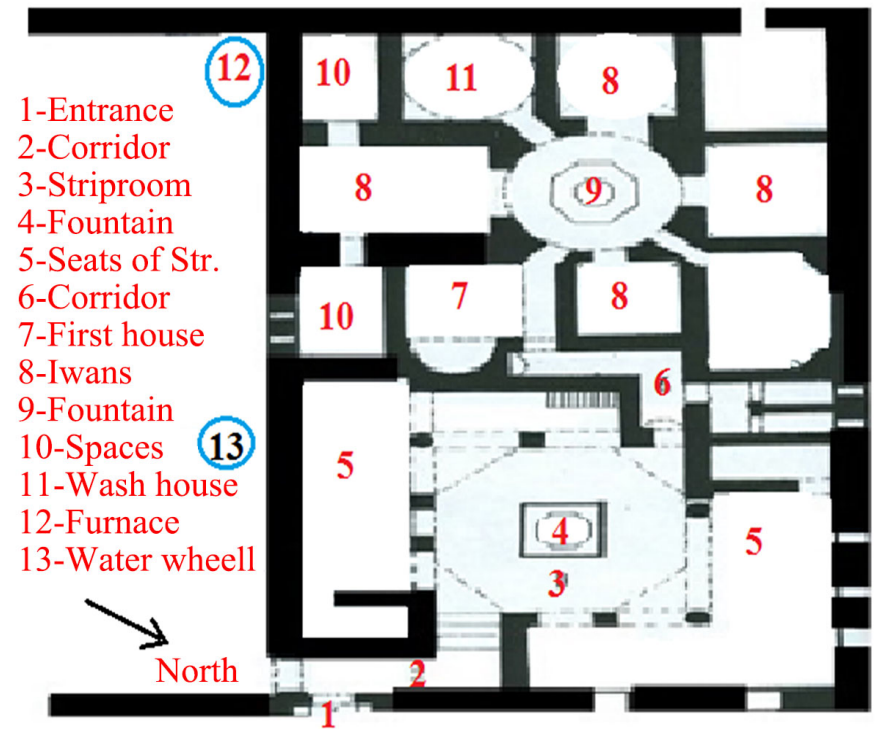

Figure 3. The horizontal design of the Ottoman Bathroom.

\subsubsection{Interior Design of the Bathroom}

The building layout included curved corridor has a wooden roof leading to a strip room covered with a wooden roof and a skylight; it occupies an area approaching to half of the Bathroom, it has a square courtyard with a fountain located in the center, the area of the courtyard is $(47.61) \mathrm{m}^{2}$, it has iwans from the four sides rise $(60) \mathrm{cm}$ from the ground, in south of the courtyard there is a stairway leading to roof of the Bathroom, and in western side there is a door leading to the second corridor, which its length is $(4.8) \mathrm{m}$, it connects between the strip room and first house. The first house opens on the heat house, and a fountain in the center, it contains four iwans that have the same size, from the heat house we get to the wash house (Figure 3). 

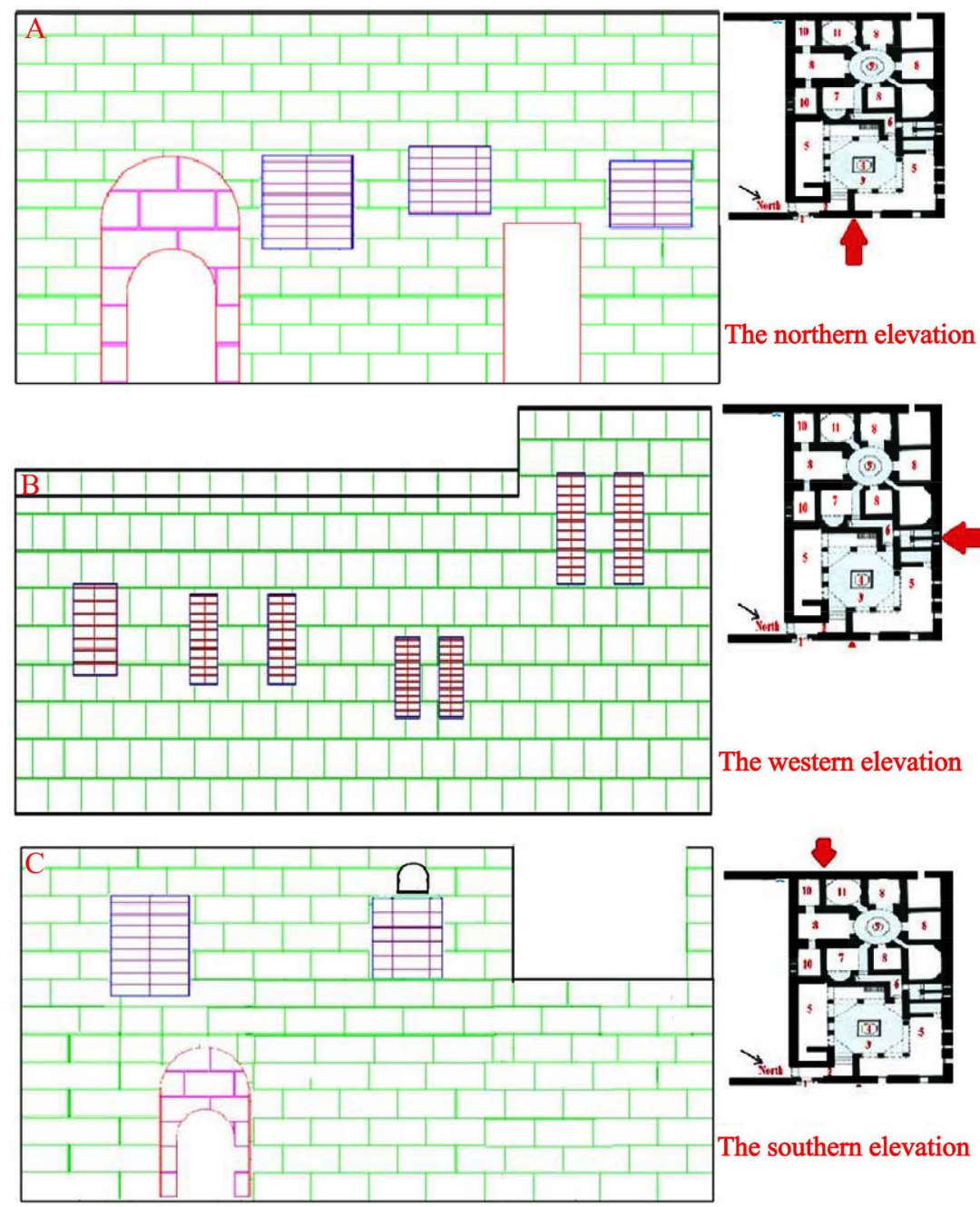

The southern elevation

Figure 4. A. The main facade of the Bathroom B. The western façade C. The southern façade.

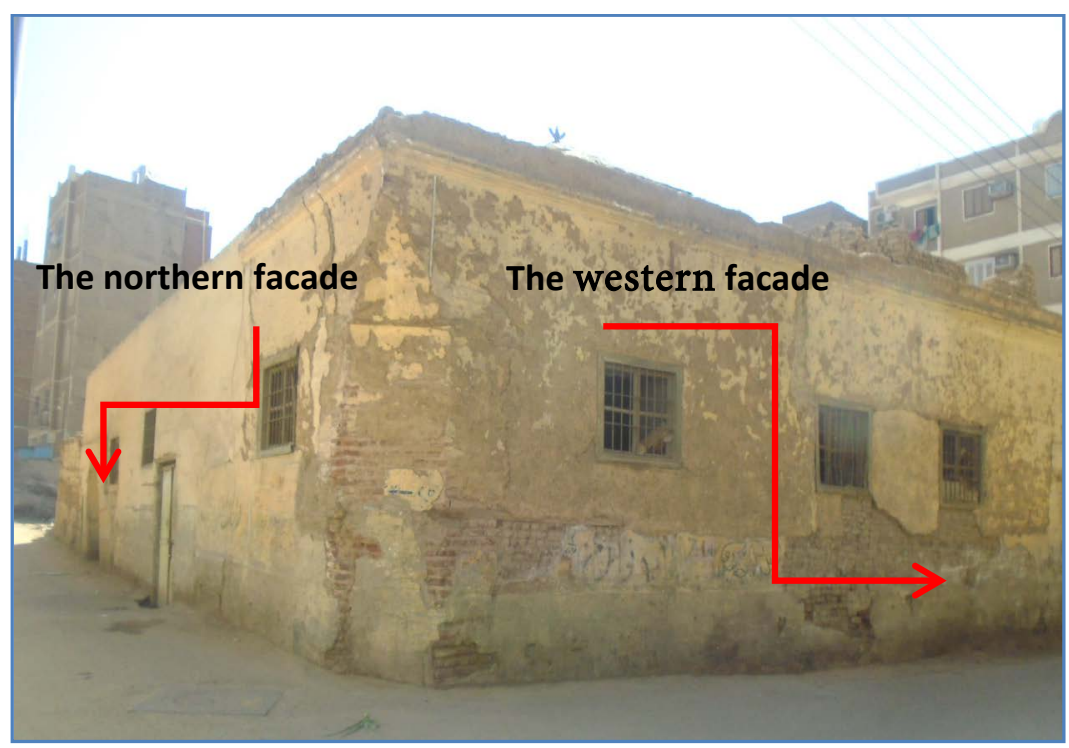

Figure 5. The northern, western facades of the Ottoman Bathroom. 


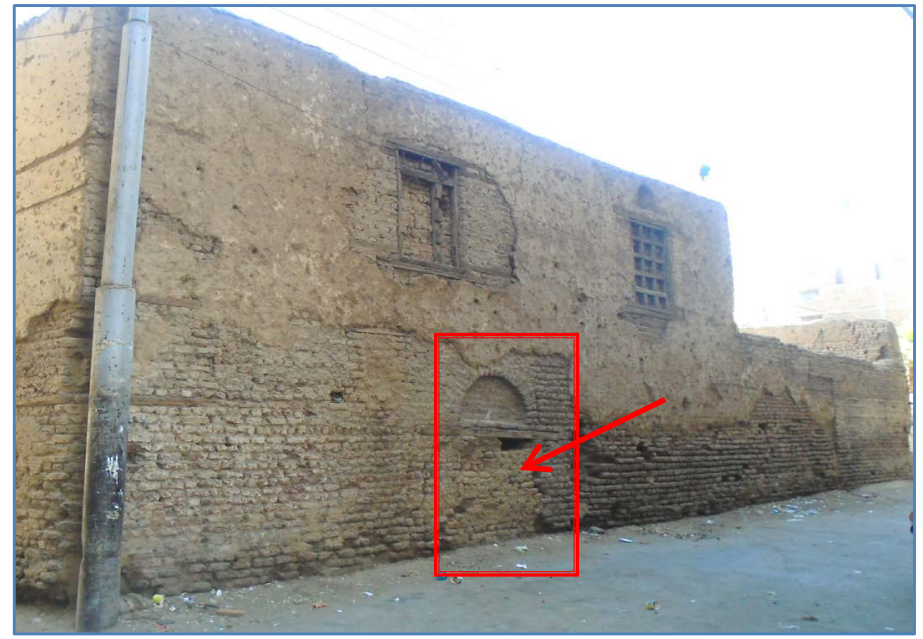

Figure 6. The southern façade of the Ottoman Bathroom.

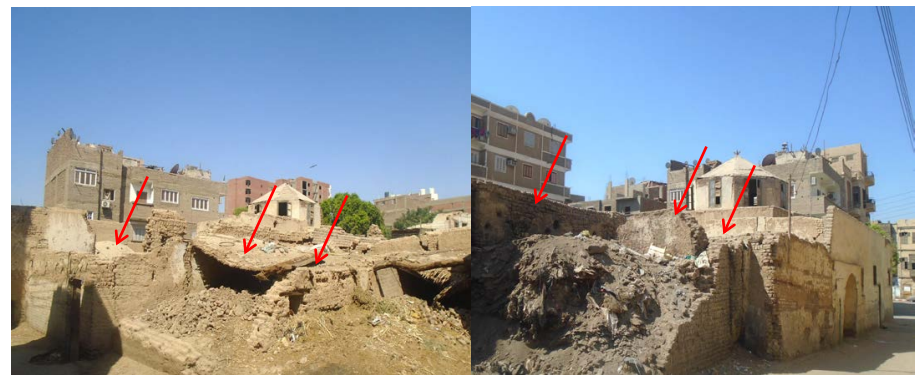

Figure 7. The eastern side of the Ottoman Bathroom.

\subsection{Deterioration Aspects of the Ottoman Bathroom and Its Surrounding}

\subsubsection{Deterioration Aspects of the Building}

The Bathroom site is surrounded by urban growth which represents a source of visual distortion and physical damage due to rising groundwater level under foundation of the building, this as well as the partial loss of the components of the building in addition to partial loss of the architectural units themselves, so it has been in bad physical condition and there is a possibility of further deterioration, damage and failure, due to that the building has been suffering damage factors and causes since far times because of the destructive reuse, floods in Qena in 1954 and effect of saturated soil with contaminated water, it is also suffering damage factors and causes at the moment such as moisture, housing ,urban trespasses and man-made destruction, ground water raised, pollution and infection of ground water beneath the Bathroom foundation.

Red bricks and mortars are the essential building materials that have been used for the construction of the Ottoman Bathroom, in addition to marble, stucco windows, mosaics, wood, and metals, etc. as secondary construction materials. Different types of weathering forms were observed in building materials of case study, such as the efflorescence of salts, due to effect groundwater. The ground water containing various kinds of mineral salts, in which they are the 
most important physiochemical weathering and damage processes that affect building materials (Hemeda et al., 2018; Binda, 2006), when water rise to the brick pores by capillary the salts will penetrate the pores, if the water dries the salts will crystallize. The salts generate internal pressure could lead to cracks in the fabric of red bricks, which turn it into a powder on long term (Lourenço et al., 2014). The Bathroom is in bad condition due to misuse and effect of different deterioration factors, such as, rising groundwater level, settlement of soil, frequency between temperature and relative humidity, in addition to lack of attention to restoration and maintenance of the building, we are observed that there are various deterioration symptoms in building material, such as, loss of building materials (red bricks and mortars), flaking and crumbling of plaster layer, accumulation of dust and salt particles on materials surface, different sizes of cracks in walls, loss of parts from the internal walls, loss of mortar layers, rise of groundwater level, efflorescence salts on building materials, loss and deterioration of wooden elements, addition to the misuse and accumulation the dust and garbage inside of the Bathroom, loss of most of the mosaic floor of the fountain, and partial loss of the roof (Figure 8).

\subsubsection{The Urban Zone of Ottoman Bathroom}

In beginning of the 19th century Qena has gained a great position among the cities of Egypt because of its geographical location, which linking Egypt and its ports on the Red Sea; in beginning of the 20th century the city has significantly grown, as a result to several factors that the city was a major center for commercial and administrative activities in that period. Therefore, the residential block increased from $0.17 \mathrm{~km}$ to $0.52 \mathrm{~km}$ by the end of the twentieth century. During the 20th century the urban growth of case study were in four periods, as the following: the $1^{\text {st }}$ period was from 1903 to 1954 , the $2^{\text {nd }}$ period was from 1954 to 1955 which the city was hit by floods, the $3^{\text {th }}$ period from 1955 to 1978 , and the $4^{\text {th }}$ period from 1979 to 1999 (Table 1 \& Figure 9).

The site of Ottoman Bathroom lacked to sewage network a long-term, so the soil contaminated with sewage water that affected on the building materials of the Bathroom and other physical and chemical properties, the urban deterioration aspects were shown the following:

- Non-commitment with standards of the build, according to the standards of Nation Organization for Urban Harmony;

- The urban surrounding is suffering from an irregularity of the region texture and non-compliance with building requirements, addition to that the buildings are bad condition;

- The urban surrounding is characterized by interlaced texture, and narrow streets;

- Lack of awareness of the historical value of the Bathroom between area residents, as well as the spread of environmental pollutants and collection of the garbage close to the monument. 


\section{Methods and Materials}

\subsection{Construction of the Study Database Subsystem}

Software programs were used in construction of the database, in the following: Terra incognita program was used to loading of Satellite photos, Arc Map 10.3 was used to drawing, linking, classification, query, analysis, and output of the spatial data, ERDAS Imagine program was used in the classification of land uses, Google Earth Program, Microsoft Excel, and Microsoft Access was used in Design and link databases. The ottoman bathroom built with fired bricks, mortars, and wooden roofs (Wheatley, 2000; Perttula et al., 2011).

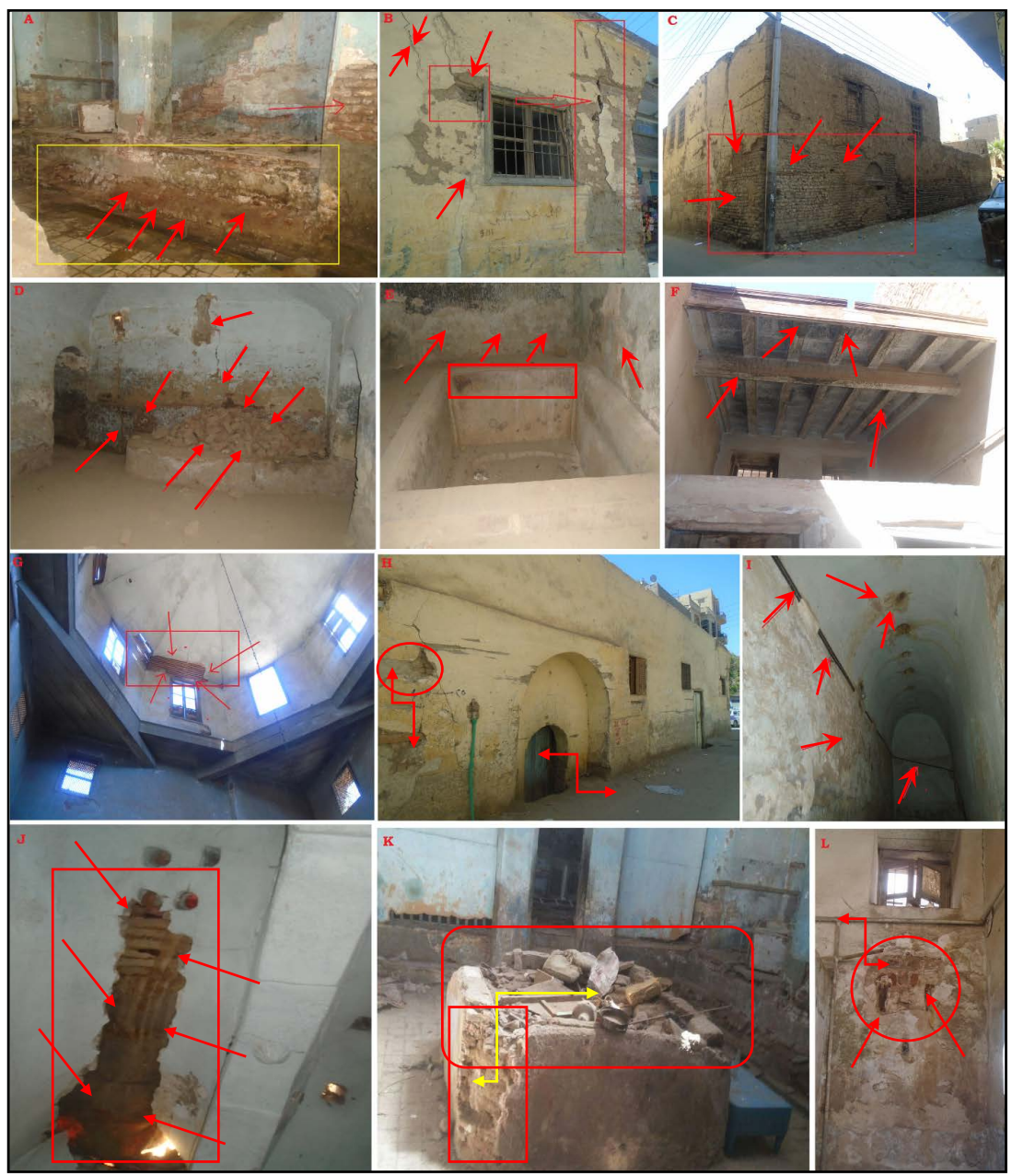

Figure 8. Deterioration aspects of the Bathroom: A) Erosion of bricks surface due to effect of groundwater and damage of the fountain. B) Cracks in the upper parts of the northern façade. C) Loss of mortar layer in the southern and the western façades. D) Shows neglect and misuse in Iwan of The Striproom. E) Salt efflorescence and cracks in walls with thick layers dropping off and accumaltion of dust in the basin. F) Splitting in wooden roof and the paint flakes with thick layers dropping off in big particles. G) Partial loss of Plaster layer in skylight. $\mathrm{H}$ ) Shows rise of the level of the street about the level of the entrance. I) Use of electricity network with bad shape. J) partial loss of the vaulted roof of the corridor. K) Damage of fountain of the striproom partial. L) Loss of plaster layer, and salt efflorescence on wall surface. 


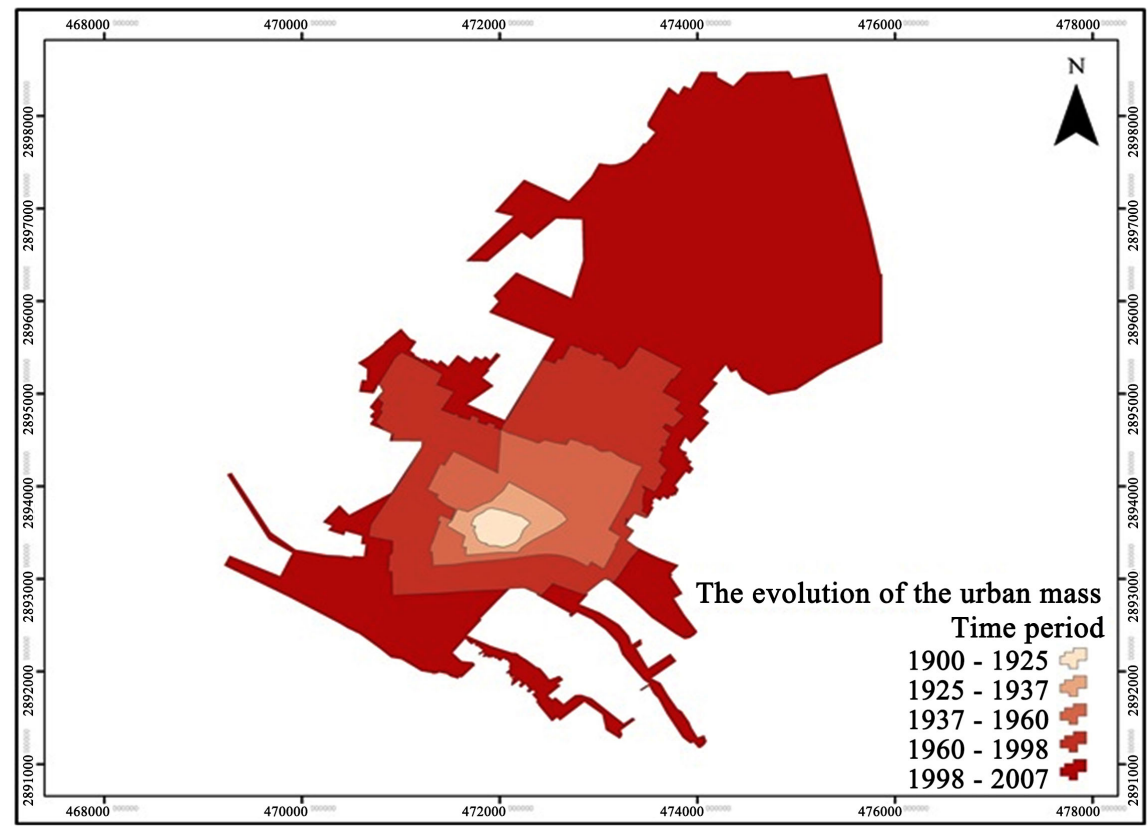

Figure 9. Directions of the urban growth of Qena city.

Table 1. Urban growth rate in the Ottoman Bathroom zone from 1800 to 1999.

\begin{tabular}{ccccc}
\hline Year & North \% & East \% & South \% & West \% \\
\hline 1800 & - & & & \\
1898 & 51.8 & 21.4 & 3.6 & 23.2 \\
1954 & 61.7 & 13.5 & 18.3 & 6.5 \\
1979 & 29.3 & 20.6 & 16.8 & 33.3 \\
1999 & 49.4 & 4.1 & 17.7 & 28.8 \\
\hline
\end{tabular}

\section{Data collection and correction}

This step is included the spatial data, all forms of data of case study, when it represents as maps, spatial data are classified into three groups of features, in the following: point features, line features, and areal features.

\section{The geographical data input and the construction of the database}

In this step, the data input that collected about the case study was carried out, where all information is transferred from the paper format to the digital format that can be handled by the computer through geographic information systems.

\section{Data storage and retrieval subsystem}

This step is included the storage of geographical data from different sources, like maps, digital data and descriptive in different styles: points, lines, closed spaces and spreadsheets, which are linked together to make it easy to call them as a layer or layers when needed.

\section{Data manipulation and analysis subsystem}

In this step change the style, level of data, remove input errors and update the data, in addition to procedure some computations, such as determination of spaces, distances and the urban zones.

Data display and reporting subsystem

This step is represented in presentation of all or some of the original data in 
the database with different ways, such as mapping, display, modified data, graphs, images, video movies, reports, composites reports and tables, as well as the definition of features, dimensions, the calculation of distances, spaces and spatial research (Aghasi, 2019).

\subsection{Investigation Methods}

The red bricks and mortar samples were collected from different places in the Ottoman Bathroom; the samples represented walls, mortar, and plaster layers. They generally consisted of damage layers.

\section{Scanning Electron Microscope}

The deteriorated samples were investigated by SEM JEOL JSM 5500 LV to identify the morphology of the bricks and used to examine the micro deterioration in the internal structure of building materials, samples were coated with gold.

\section{X-Ray Diffraction (XRD)}

$\mathrm{X}$-ray diffraction method was carried out on deteriorated building materials samples; to study the changes in chemical composition of the samples was performed in Micro Analytical Unit, faculty of archaeology, Cairo university, and was carried by X-ray diffraction patterns, using a Philips X-ray PW 1840 diffractometer with $\mathrm{Cu}-\mathrm{Ka}$ radiation generated at $40 \mathrm{kV}$ and $40 \mathrm{~mA}$. It covers $2^{\Theta}$ from 50 to 500 .

\section{Results}

\subsection{Evaluation of Urban, Social, and Economic Characteristics}

The geographic database of the Ottoman Bathroom and its surrounding included geographic maps about of the construction state of the buildings, land uses, the construction method, sewage and drinking water networks.

Through analytical study for the urban surrounding and assessment of the current state of the land uses, the results revealed the following:

- From the evaluation of the structural state of the buildings in surrounding of the Bathroom, show that $37 \%$ of the buildings are cracked, $34 \%$ are good, $18 \%$ are bad, and $11 \%$ are ruined (Figure 10 ). The height of the buildings is ranging from one to five of the floors (Figure $11 \&$ Figure 12).

- From the assessment of structural style of buildings, show that $27.77 \%$ were built of walls and concert roofs, $27.77 \%$ were built of mud bricks, $20.37 \%$ were built of walls and wooden roofs, and 5.55\% were built of concrete buildings (Table 2, Table 3 \& Figure 13 \& Figure 14).

- $74.07 \%$ of the buildings are residential buildings, $18.51 \%$ are space lands, $1.85 \%$ are commercial buildings, $1.85 \%$ are administrative buildings, and $1.85 \%$ are mixed residential buildings (Figure 14).

- From social statistics which were performed on population, we were observed that $54.8 \%$ of the population have a free activity, and $31.7 \%$ are working in the government sector, from the analytical studies of economic statis- 
tics were indicated the urban surroundings haven't any economic development, although the high price of the land.

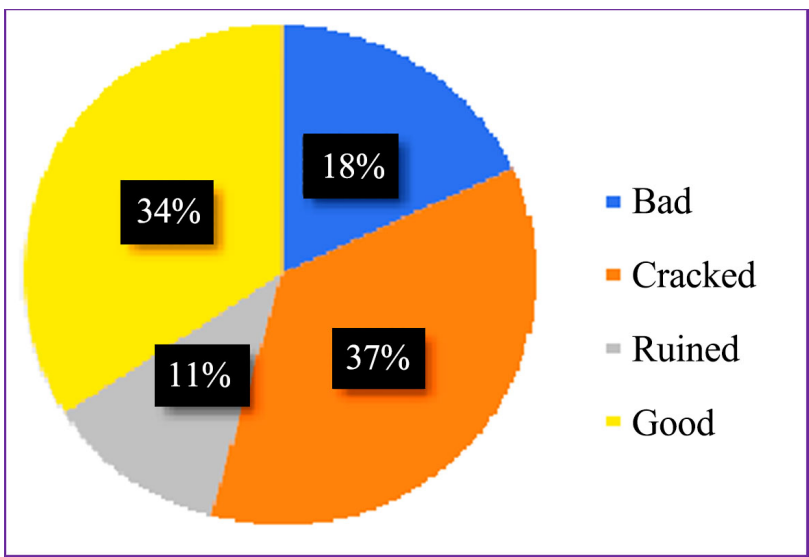

Figure 10. Diagram of thestructural state of buildings.

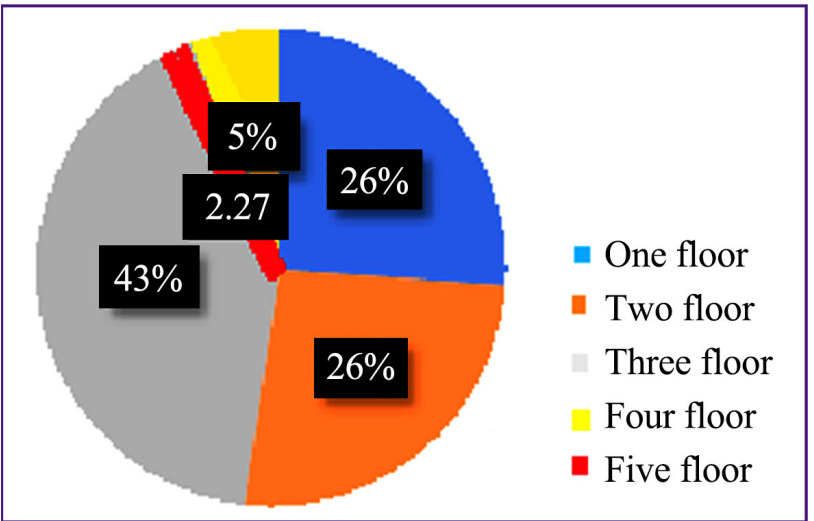

Figure 11. Diagram of the height rating of buildings.

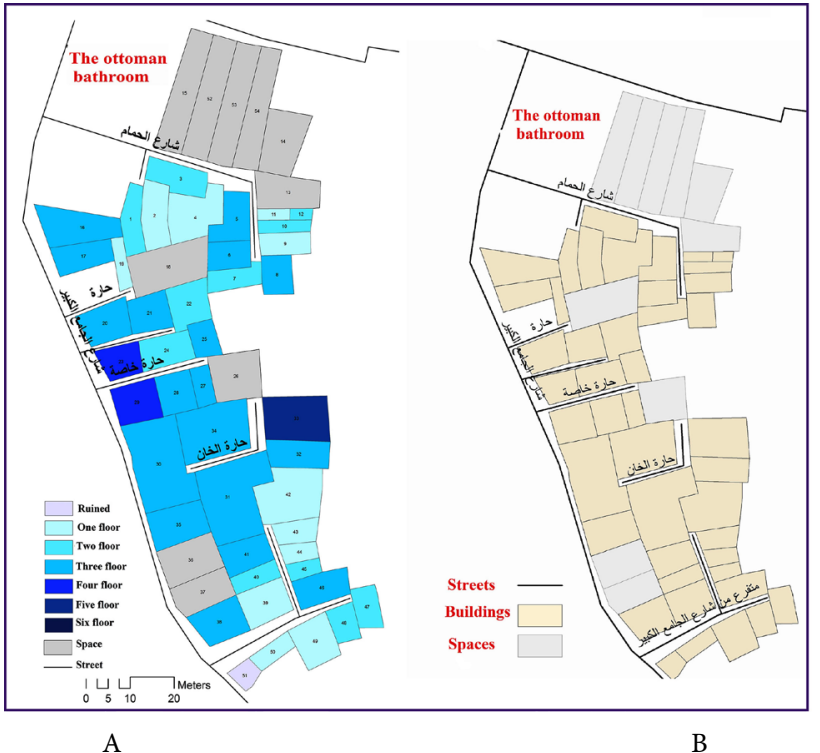

Figure 12. A. Shows height of the buildings. B. Shows a map of streets in Bathroom site. 


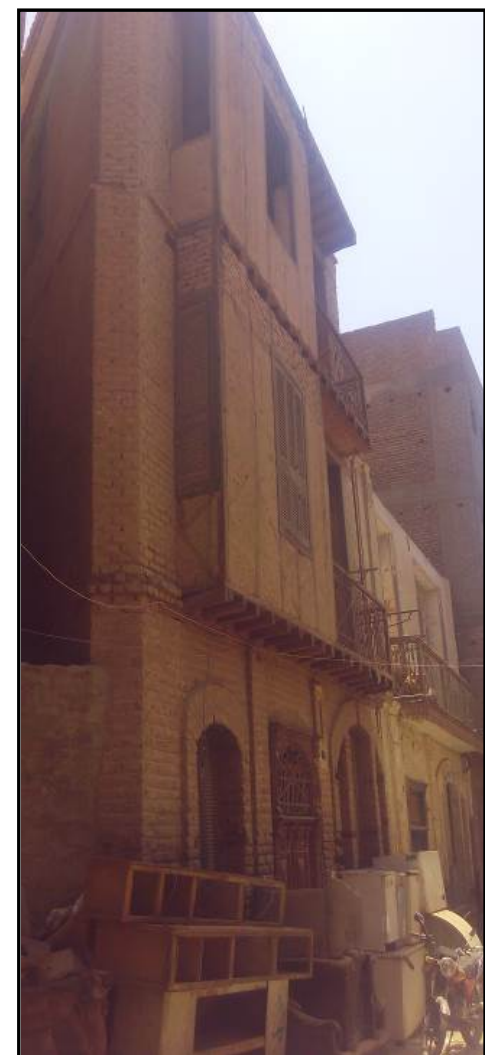

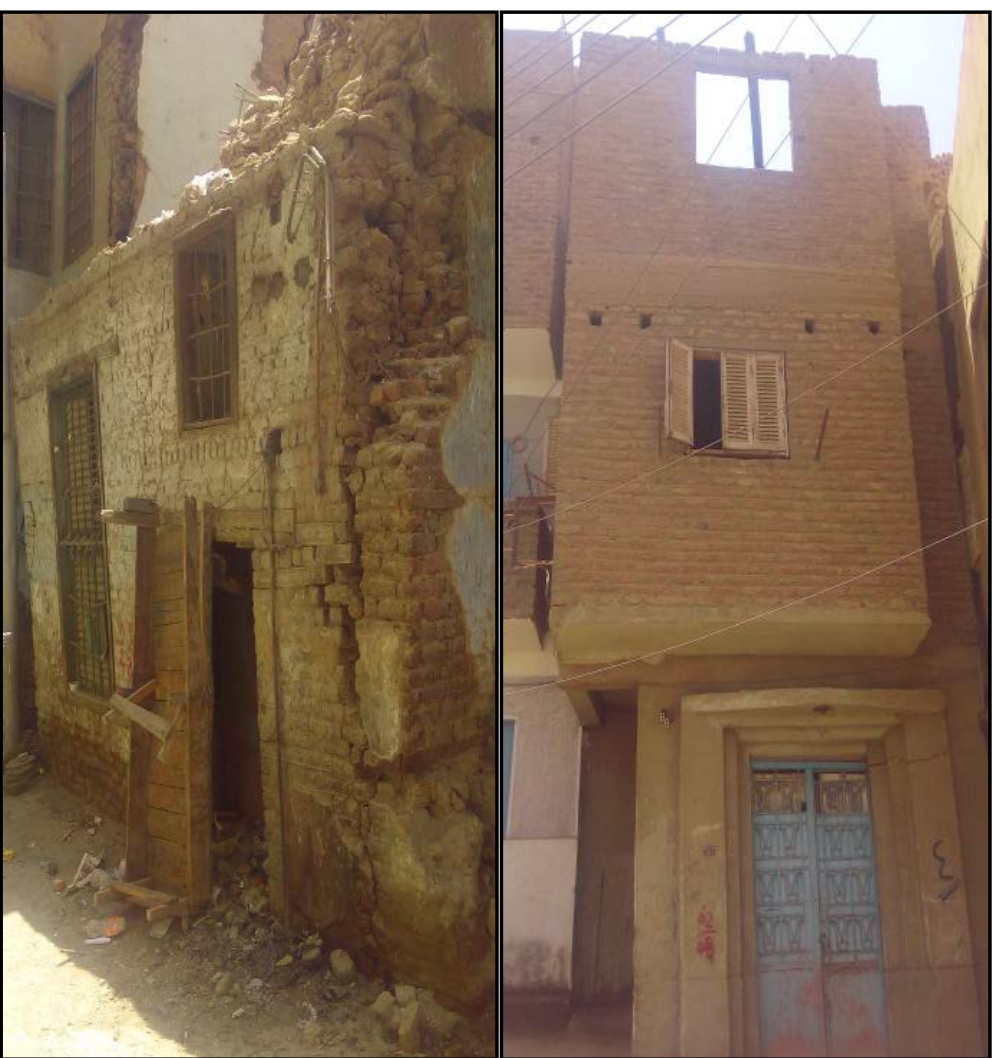

B

C

Figure 13. A. Shows the buildings were built by walls and concert roofs. B. Shows the buildings were built by mud bricks. C. Shows the buildings were built by walls and wooden roofs.

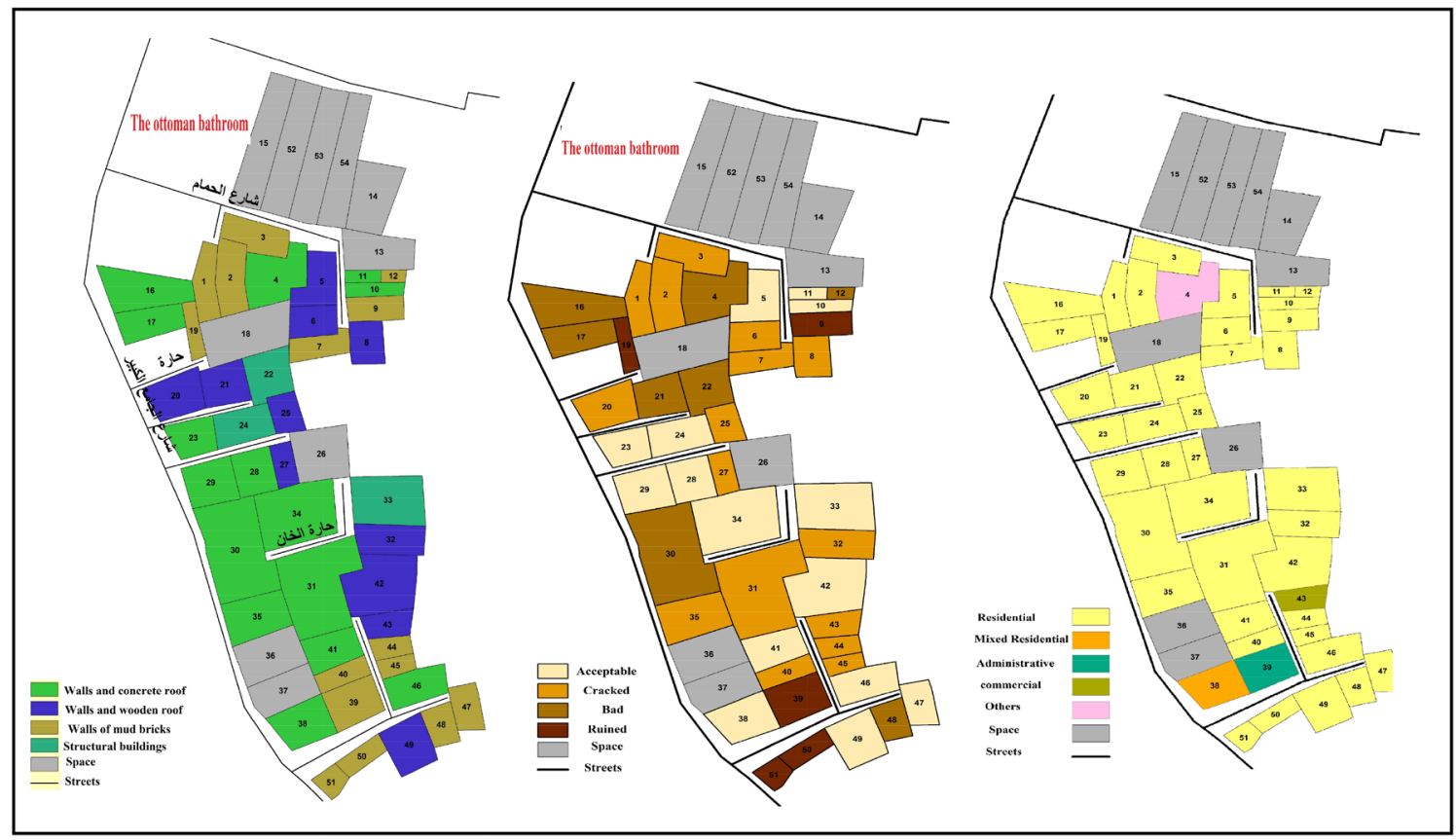

A

Figure 14. A. Database by GIS is shown construction style of the buildings. B. Database by GIS is shown construction state of buildings. C. Database by GIS is shown land uses. 
Table 2. The land uses of surrounding of the Bathroom.

\begin{tabular}{ccc}
\hline Cat. & Number & per. \% \\
\hline Residential & 40 & 74.07 \\
Mixed Residential & 1 & 1.85 \\
Administrative & 1 & 1.85 \\
Commercial & 1 & 1.85 \\
Space & 10 & 18.51 \\
\hline
\end{tabular}

Table 3. The structural style of the buildings.

\begin{tabular}{ccc}
\hline Cat. & Number & per. \% \\
\hline Walls and concert roofs & 15 & 27.77 \\
Walls and wooden roofs & 11 & 20.37 \\
Walls of mud bricks & 15 & 27.77 \\
Structural buildings & 3 & 5.55 \\
Space & 10 & 18.51 \\
\hline
\end{tabular}

\subsection{The Current State of Building Materials of the Bathroom}

\subsubsection{SEM Investigation}

SEM image of red bricks samples are presented the deterioration places in the Ottoman Bathroom. The examination is shown weakness and cracks in bricks fiber and also shows no cohesion and interdependence with the presence of crystallized salt in the internal structure of the bricks. Deterioration, corrosion, voids and loss of binding materials observed in bricks structure. From the investigation, we observed intensive of sodium chloride between pores of bricks (Figure 15).

\subsubsection{X-Ray Diffraction (XRD)}

The red bricks samples analyses were carried out by XRD for defining the chemical components of samples. All results are shown in Table 4 and Figure 16. The results of the study show that the deteriorated bricks samples consists of Quartz $\left(\mathrm{SiO}_{2}\right)$, Feldspar, Hematite $\left(\mathrm{Fe}_{2} \mathrm{O}_{3}\right)$ as a major components, in addition to Halite $(\mathrm{NaCl})$ and Gypsum $\left(\mathrm{CaSO}_{4} \cdot 2 \mathrm{H}_{2} \mathrm{O}\right)$, in which accelerated of red bricks weathering, the salts increase the moisture content within the building materials, which dissolves the salts in the pores, and when water is evaporation occurs crystallization and recrystallization of salts causing mechanical damage to the bricks due to crystallization and recrystallization pressure.

The summary: From evaluation of the urban environment of the Bathroom by GIS technique, the results indicated that the residential buildings are represented $74.07 \%$ of the total buildings, $37 \%$ of the buildings are cracked, $34 \%$ are good and $11.5 \%$ are ruins. From the investigation study was carried by scientific techniques on building materials, indicated that there is a crystallized salt in bricks pores, such as sodium chloride and calcium sulphate, micro-cracks, loss in the internal structure of building materials, the examination is shown weakness and cracks in bricks fiber and also shows no cohesion and interdependence, the previous results contributed to evaluating the physical condition of the bathroom that shows his condition is critical and needs urgent intervention to restore. 


\section{Restoration and Rehabilitation Suggestions}

\subsection{Suggestions for Restoration and Rehabilitation of the Bathroom}

- Procedures of restoration of the Ottoman Bathroom were summarized in the following. From observation of various deterioration forms of the exterior facades of the Bathroom; the restoration steps can be defined as follows: 1) Restoration of cracks will be carried out with wooden bars method; in this method Cutting is done in bricks course with $50 \mathrm{~cm}$ length on both sides of the crack. It is possible to make a full belt around the building (Figure 17). The application of this technique is in accordance with the principles and rules of international restoration, especially the provisions of Article (10) of the Venice Charter in 1964, and Article (11) of the Lahore Charter in 1980.2) A mortar made of lime, sand and kaolin is used to fill cracks after laying of wooden bars. 3) Replacement of damaged bricks with red bricks having the same chemical and physical properties. 4) Compensation the missing plaster layer of the facades. 5) Repair of the skylight of Ottoman Bathroom.

Table 4. X-ray diffraction analysis results.

\begin{tabular}{ccccccc}
\hline Sample tite & Quartz & Calcite & Feldspar & Hema & Halite & Gypsum \\
\hline RB1 & 50 & 20 & - & 10 & 12 & 8 \\
RB2 & 45 & 18 & 22 & 15 & - & - \\
RB3 & 44 & 10 & 26 & 20 & - & - \\
RB4 & 78 & 10 & - & - & - & 12 \\
\hline
\end{tabular}
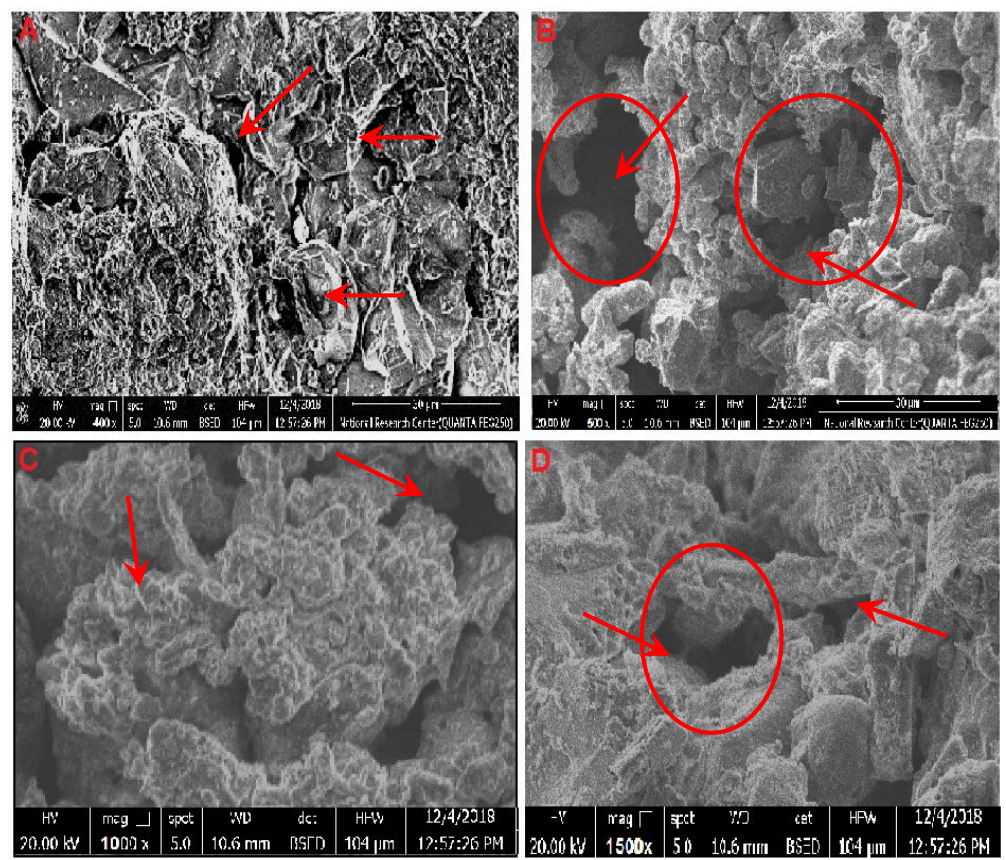

Figure 15. SEM Photographs of red bricks. A. Showing corrosion of quartz and presence voids in bricks structure. B. Showing loss of binding materials and presence of crystallized salt. C. Showing dense of crystallized salt between pores of bricks. D. Presence of voids and salts in bricks structure. 


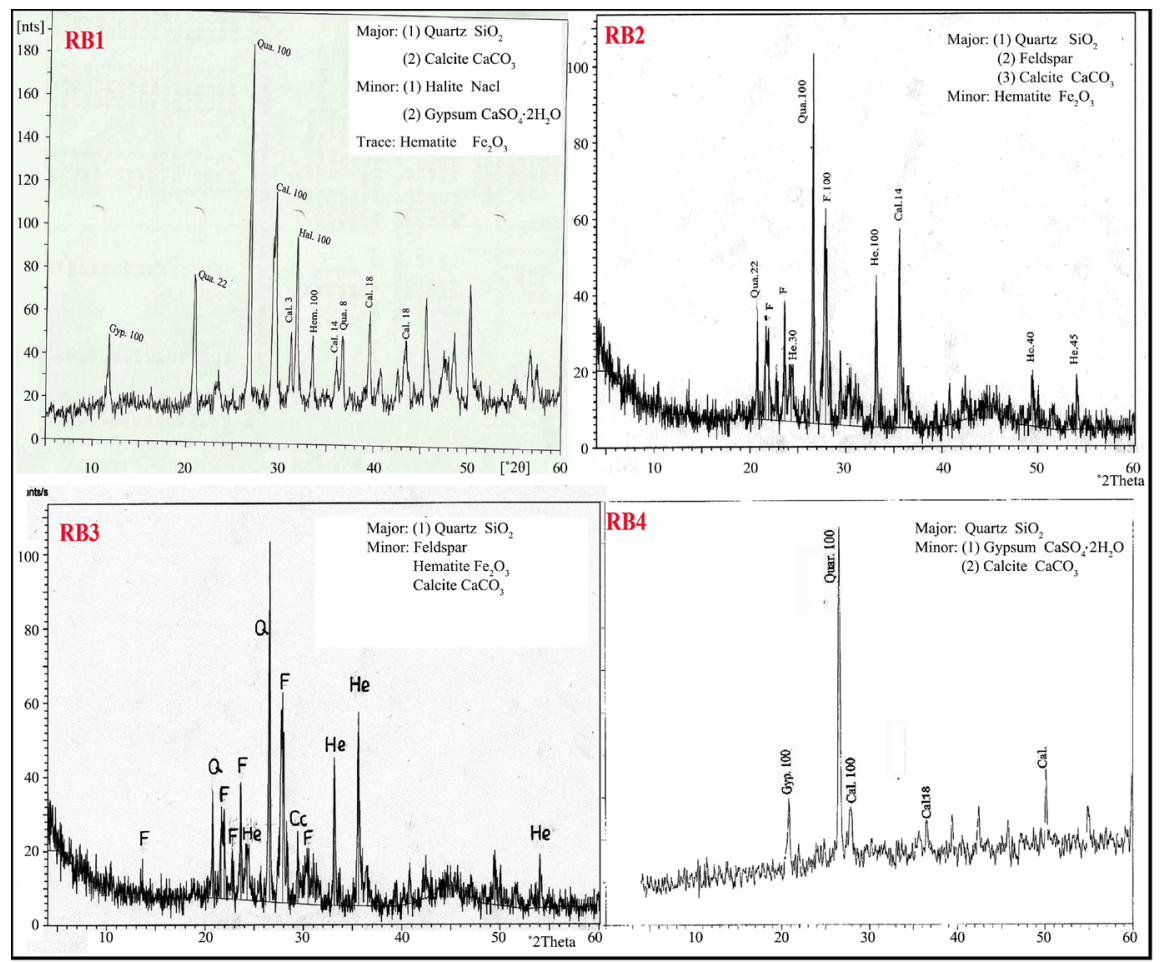

Figure 16. XRD pattern of the red bricks samples presented case study.

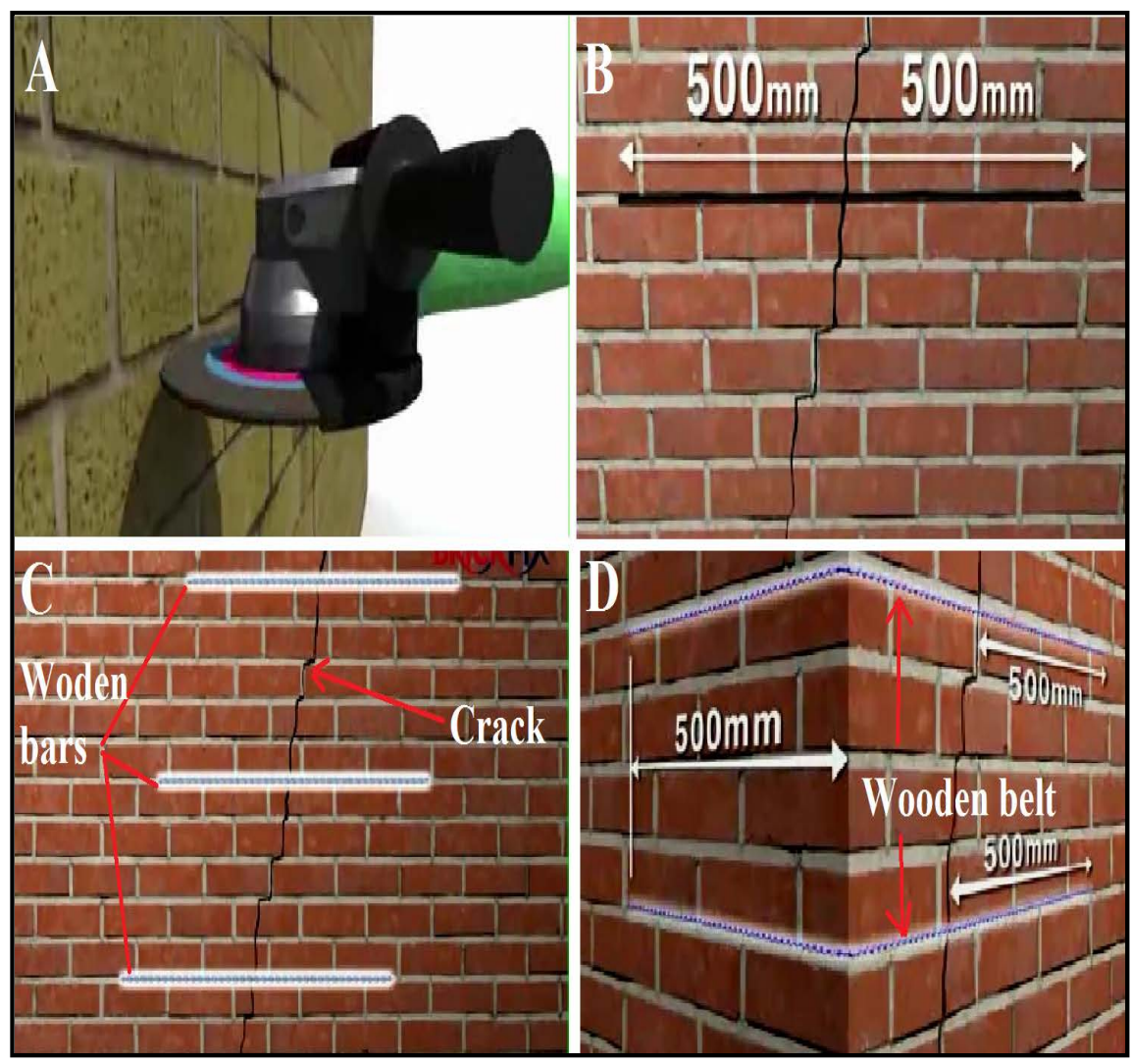

Figure 17. Showing stages of cracks Stitching. (A) Cutting in bricks course. (B) Cleaning the cutting in the course. (C) Install wood bars in the cutting on sides of the cracks. (D) Install wooden belt in corners of the build. 
- From monitoring of deterioration symptoms in the interior of the Bathroom, the restoration steps can be defined as follows: 1) Removing dust and debris inside the Bathroom rooms. 2) For the walls, the damaged plaster layers will be removed, the salts will be extracted, replacement of damaged bricks, then the walls will be consolidated, and put the plaster layers. 3) For the floor of the Bathroom, the floor slabs are disassembled and the floor is consolidated, then reassembly the floor slabs and completes the missing ones with the same materials used in the past. 4) Repair windows and doors and replacement damaged ones. 5) Reconstruction of destroyed Bathroom annexes with the same design used in the past. Renovation of the infrastructure of the Bathroom while preserving the ancient archaeological appearance. 6) Repairing and restoration any damage to artworks such as stucco windows and mosaic floors.

- Adaptive reuse: In accordance the article (5) of the Venice Charter of 1964, article (5) of the Convention for the Protection of the World Cultural and Natural Heritage of the 1972 General Conference of UNESCO, and article (8) of the Charter for the Preservation of Cities and Historic Sites, Washington, 1987. We will show the policy of the Bathroom reuse in the following: 1) The Bathroom will be reuse in the same old function, as physiotherapy center. 2) Determine the rehabilitation of the building in its current form to perform its old functions, which the architectural elements of the building are designed according to their role. 3) The policy of reuse of the building is one of the most important steps to the preservation, and provides self-financing for urban and social development projects in the area of the Bathroom. 4) The re-employment of the Bathroom leads to the development of the surrounding community through the services that the building can provide it, and the involvement of the population in the conservation works 5) The building reuse is work to increase the tourist attraction of the Bathroom area.

\subsection{Rehabilitation of the Bathroom Surrounding}

Proposals of the upgrading of the urban surrounding of the Ottoman Bathroom were carried in the following: 1) Determine the borders of macro and micro context of the old Qena city, addition to determine of the major streets for reaching to the area (Figure 18). 2) Design a database by GIS for the road, sewerage, drinking water, electricity distribution, and communication lines networks (Figure 19). 3) Modernization of infrastructure in the Bathroom surrounding. 4) Removing collapsed houses and replacement it with houses compatible with the region's historical style. 5) Conceptualize for services areas in the surrounding of the bathroom (Figure 20).

\section{Conclusion}

This research paper constitutes an integrated approach to illustrate the role of Geographic Information Systems (GIS) in the conservation of historic buildings 


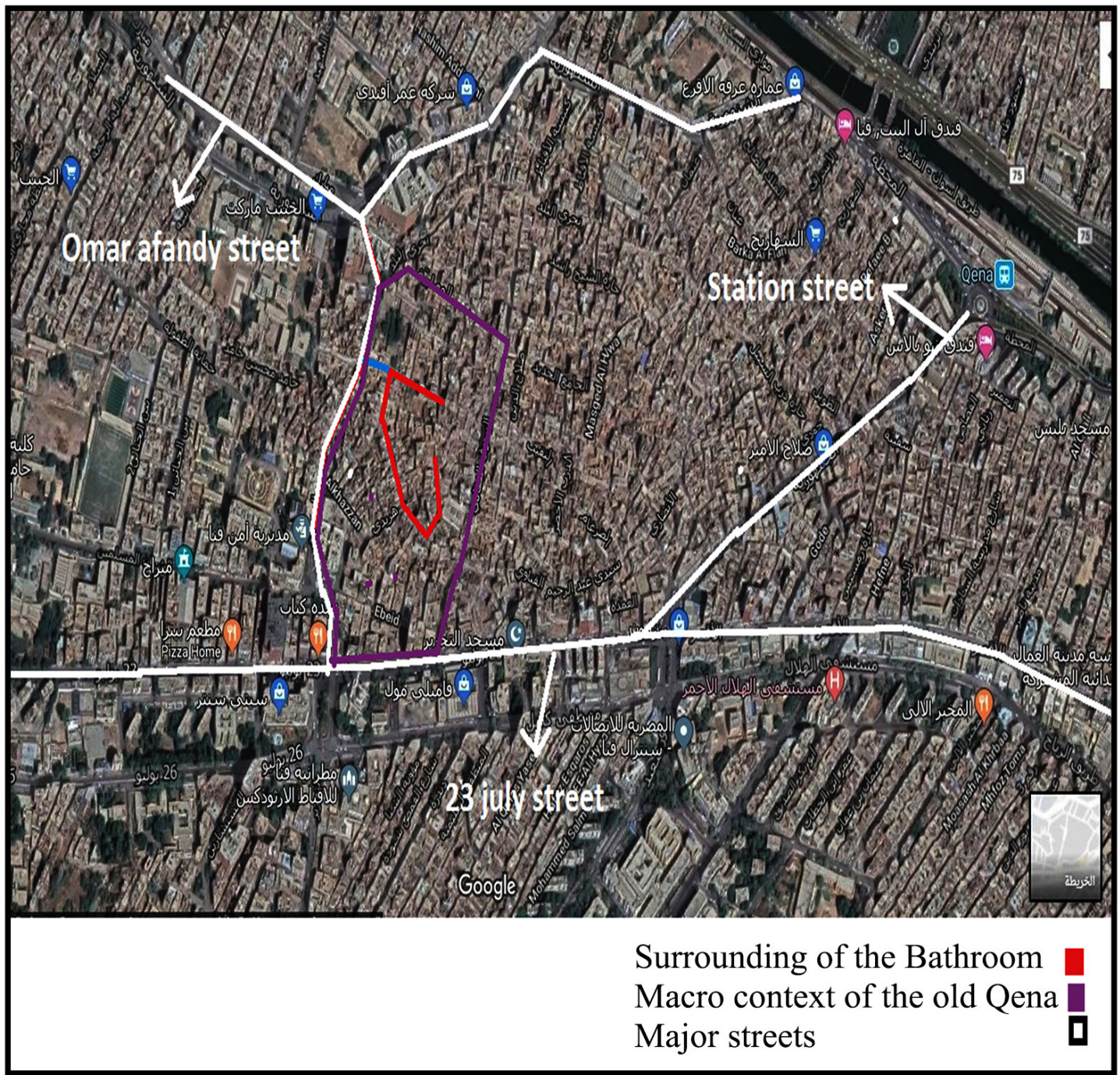

Figure 18. Shows site of the Ottoman Bathroom and its surrounding (Goog earth).

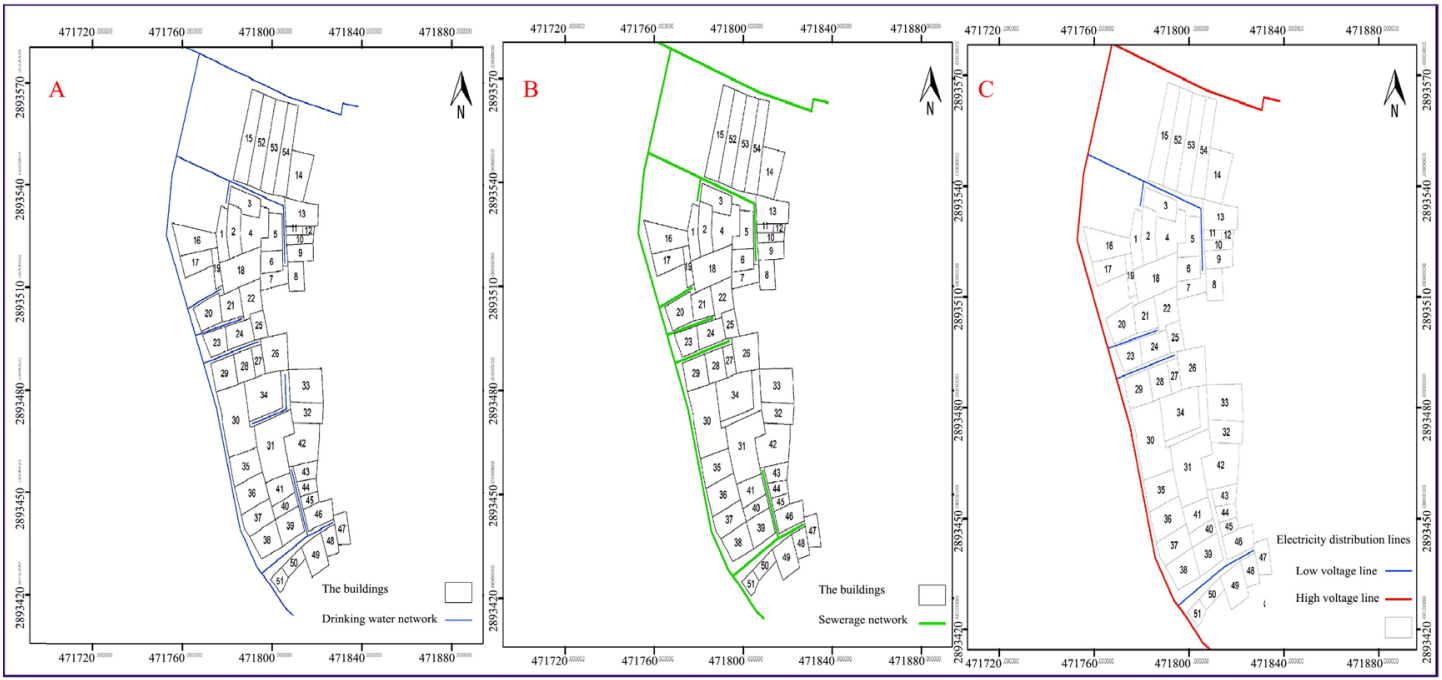

Figure 19. Shows A. Database by GIS is shown drinking water network. B. Database by GIS is shown sewerage network. C. Database by GIS is shown electricity distribution network. 


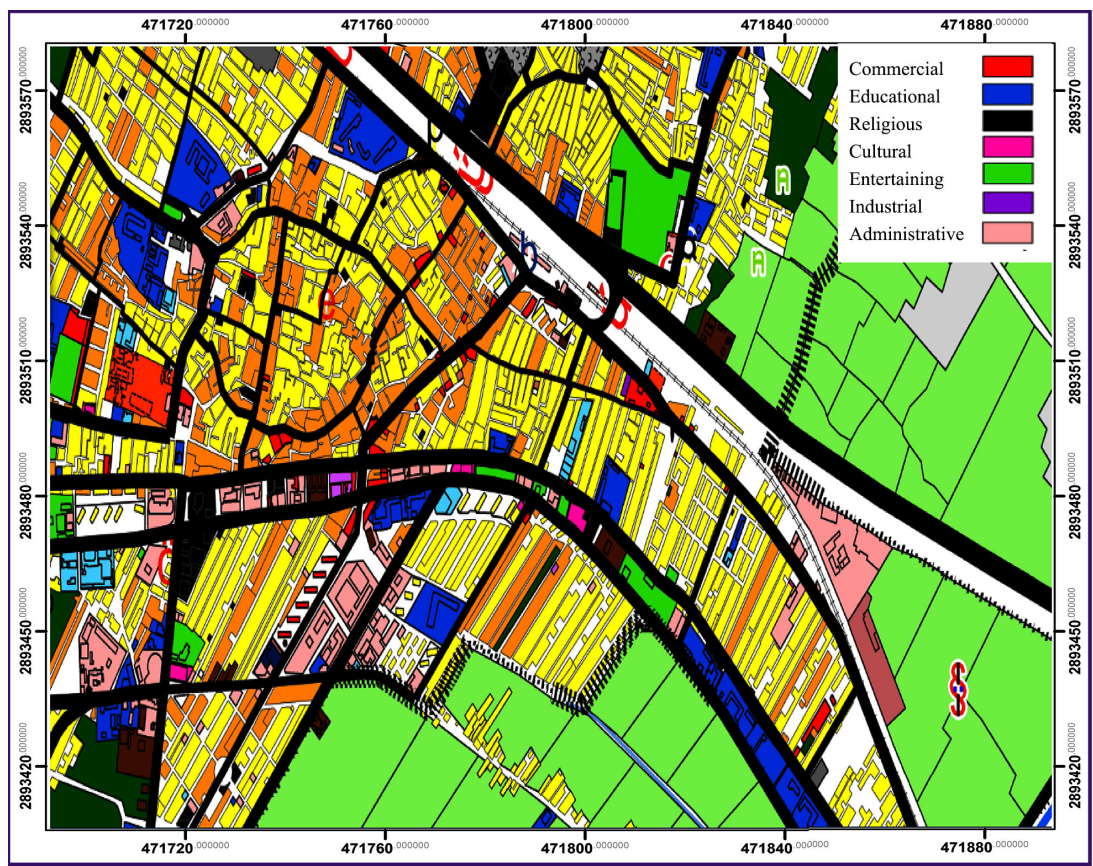

Figure 20. Shows a vision for upgrading of the services in the surrounding of the Bathroom.

through providing an integrated database of the monument, which is useful in evaluating the current state of the Ottoman Bathroom and its urban surrounding in Qena city, which will be used to support the decision in the conservation and reuse of the Bathroom. The results of the study indicated that the urban surrounding of the Ottoman Bathroom area has compact texture, and suffering from an irregularity of the region texture, it is concluded that the current state of the buildings in the Bathroom area represents $37 \%$ of the buildings are cracked, $11.5 \%$ are ruined. We observed that the Ottoman Bathroom in bad physical condition and there is a possibility of further deterioration damage and failure, due to that the building has been suffering damage factors and causes since far times because of the destructive reuse; this confirmed with the investigation and analysis that carried out on building materials. The paper is concluded that GIS technique is a suitable method for the rehabilitation of the Ottoman Bathroom and surrounding environment, with necessity to reuse of the Bathroom in the same old function to preserve, revitalize and benefit it in the tourism development of Qena city. Where GIS technique is used in determing the borders of macro and micro context of the old Qena city, in addition to determining of the major streets for reaching the area, design maps of sewerage, drinking water, electricity distribution, and communication lines networks, in addition to design of database for modernization of infrastructure and conceptualize for services areas, which will perform in the surrounding of the bathroom.

\section{Acknowledgements}

I would like to thank Mr. Hythem Shaapan Khalaf, specialist of geographic in- 
formation systems for his cooperation and valuable efforts in this research.

\section{Conflicts of Interest}

The author declares no conflicts of interest regarding the publication of this paper.

\section{References}

Aghasi, N. H. M. (2019). Application of GIS for Urban Traffic Accidents: A Critical Review. Journal of Geographic Information System, 11, 82-96.

https://doi.org/10.4236/ad.2018.64017

Akhter, H. (2018). The Methods and Recent Invented Tools and Techniques Used in Archaeology for Delicately Preserving the Past for the Future. Archaeological Discovery, 6, 338-354. http://creativecommons.org/licenses/by/4.0/ https://doi.org/10.4236/ad.2018.64017

Aldenderfer, M.S., \& Carolyn, A. H. (2000). The Small-Scale Archaeological Survey Revisited. American Archeology, 4, 4-5.

Benavente, D., del Cura, M. G., Garcı-Guinea, J., Sánchez-Moral, S., \& Ordóñez, S. (2004). Role of Pore Structure in Salt Crystallization in Unsaturated Porous Stone. Journal of Crystal Growth, 260, 532-544. https://doi.org/10.1016/j.jcrysgro.2003.09.004

Binda, L. (2006). The Difficult Choice of Materials Used for the Repair of Brick and Stone Masonry Walls. In 1st International Conference on Restoration of Heritage Masonry Structures (pp. 1-16). http://hdl.handle.net/11311/242096

Chang, K. T. (2008). Introduction to Geographic Information Systems (Vol. 4). Boston, MA: McGraw-Hill.

El Adnani, A., Habib, A., El khalidi, K., \& Zourarah, B. (2019). Spatio-Temporal Dynamics and Evolution of Land Use Land Cover Using Remote Sensing and GIS in Sebou Estuary, Morocco. Journal of Geographic Information System, 11, 551-566. https://doi.org/10.4236/jgis.2019.115034

Elphinstone, M., \& Wickham-Jones, C. (2012). Archaeology and Fiction. Antiquity, 86, 532-537. https://doi.org/10.1017/S0003598X0006292X

Godchild, M. F., Haining, R., \& Wise, S. (1992). Integrating GIS and Spatial Data Analysis: Problems and Possibilities. International Journal of Geographical Information Systems, 6, 407-423. https://doi.org/10.1080/02693799208901923

Güney, C. (2001). Multimedia Supported GIS Application: Ottoman Castles Information Systems. Magazine of "Sanal Gazete", 6, 13.

Hemeda, S., Khalil, M., Shoeb, A., \& EL Aziz, A. A. (2018). The Effectiveness of Nano Materials and Nanomodified Polymers for Preservation of Historic Brick Masonry in Rashid, Egypt. International Journal of Conservation Science, 9.

Lake, R. W. (1993). Planning and Applied Geography: Positivism, Ethics, and Geographic Information Systems. Progress in Human Geography, 17, 404-413.

https://doi.org/10.1177/030913259301700309

Lock, G. (2001). Theorising the Practice or Practicing the Theory: Archaeology and GIS. Archaeologia Polona, 39, 153-164.

Lourenço, P. B., van Hees, R., Fernandes, F., \& Lubelli, B. (2014). Characterization and Damage of Brick Masonry. In Structural Rehabilitation of Old Buildings (pp. 109-130).

Berlin, Heidelberg: Springer. https://doi.org/10.1007/978-3-642-39686-1_4

Meaden, G. J., \& Aguilar-Manjarrez, J. (2013). Advances in Geographic Information Sys- 
tems and Remote Sensing for Fisheries and Aquaculture. FAO Fisheries and Aquaculture Technical Paper.

https://search.proquest.com/openview/aa858b06ca6d54c16d52f39e0c6a48f7/1?pq-origs ite $=$ gscholar $\& \mathrm{cbl}=237320$

Mekni, M. (2013). Using GIS Data to Build Informed Virtual Geographic Environments (IVGE). Journal of Geographic Information System, 5, 548-558.

https://doi.org/10.4236/jgis.2013.56052

Moustafa, M. M. (2000). Geographical Information Infrastructure (GII) to Support Decision-making in Urban Development in Egypt. Doctoral Dissertation, Enschede, The Netherlands: The International Institute for Aerospace Survey and Earth Sciences, Department of Urban Planning and Management, ITC.

National Center for Geographic Information and Analysis. (1989). The Research Plan of the National Center for Geographic Information and Analysis. International Journal of Geographical Information Systems, 3, 117-136.

https://doi.org/10.1080/02693798908941502

Openshaw, S. (1991). A View on the GIS Crisis in Geography, or Using GIS to Put Humpty Dumpty Back Together again. Environment and Planning A, 23, 621-628. https://doi.org/10.1068/a230621

Osman, A. M. (2001). Jurisprudence of Architecture of Bathrooms in the Ottoman Period, European Influences on Ottoman Architecture and Mechanism of Conservation (p. 314). The 4th International Conference for Ottoman Archeology Code.

Perttula, T. K., Nelson, B., \& Lohse, J. C. (2011). Archeological Survey Investigations at Martin Creek Lake State Park, Rusk County, Texas. Index of Texas Archaeology: Open Access Gray Literature from the Lone Star State, 2011, 11. https://doi.org/10.21112/ita.2011.1.11

Pickles, J. (2008). Representations in an Electronic Age: Geography, GIS, and democracy. Praxis(e)Press.

https://atrium.lib.uoguelph.ca/xmlui/bitstream/handle/10214/1827/33-Pickles.pdf?sequ ence $=1$

Rajani, M. B. (2016). Cultural Heritage of Karnataka: A Remote Sensing and GIS Perspective. Bangalore: National Institute of Advanced Studies (NIAS) IISc Campus.

Ramsay, S. (2011). Secret Rock Art in the Caderbarg. Year in the Wild Blog. http://www.yearinthewild.com/secret-rock-art-in-the-cederberg/

Wheatley, D. (2000). Spatial Technology and Archaeological Theory Revisited. Bar International Series, 845, 123-132.

Wheatley, D., \& Gillings, M. (2013). Spatial Technology and Archaeology: The Archaeological Applications of GIS. London: CRC Press.

https://doi.org/10.1201/b12806 